\title{
The Impact of Foreign Direct Investment on Poverty Reduction in the Developing Countries
}

\author{
Yaser Ahmad Arabyat \\ Department of Finance, Faculty of Business, Balqa Applied University, Jordan \\ E-mail: yaser_arabyat@yahoo.com
}

Received: Sept. 19, 2017

Accepted: Sept. 28, 2016

Published: Oct. 13, 2017

doi:10.5296/ifb.v4i2.11987

URL: http://dx.doi.org/10.5296/ifb.v4i2.11987

\begin{abstract}
The aim of this study is to choose and estimate the effect of foreign investments in engine for economic growth and hence poverty reduction in the developing countries. The study concluded that there is a weak effect of non-moral of foreign investments on decreasing unemployment in the developing countries, regardless of the existence or absence of development. In addition, the study concluded with a negative effect for the total local production on unemployment and poverty. Finally, we concluded that this may be a result of profit repatriation of foreign firms, crowding out of domestic investment because of FDI or low level of human capital in the country.

Consequently, the study recommended to despite how desirable the inflow of FDI is to developing countries, care should be taken when attracting foreign investments and they should be directed to the productive sectors of the economy. Also government should create a competitive environment so as to maximize the benefits of FDI because by exposing foreign investors to an even playing field with indigenous investors.
\end{abstract}

Keywords: Direct foreign investments, Poverty, Developing countries, Human capital, International development 


\section{Introduction}

Since the transfer of GATT (General Agreement on Tariffs and Trade) to the World Trade Organization in 1995 witnessed what could be called the internationalization of the production process, or the globalization of capital due to the economic liberalization where commercial exchange relies on the market mechanism, movement of the capitals and multi-national corporation, where direct foreign investment is viewed as a main source for the special capital and a means to speed the economic growth in the developing states (Baksh \& Polani, 2001).

In fact, no doubt that unemployment is one of the motives and reasons that make states compete on attracting foreign investment which is deemed as a life-boat that can help in eliminating poverty, or at least decrease such problem.

\subsection{Significance and Problem of the Study}

Since the beginning of the nineties, developing states have been racing to attract direct foreign investments considering that investments can achieve various advantages including decreasing poverty through its influence on the manpower of the developing states, then in decreasing the number of poor who live under poverty line (Mold, 2004). In this context, direct foreign investments can help in creating job opportunities in the host countries, and thus contribute in solving unemployment (Abu Qahaf, 1989).

\section{The problem of the study focuses on answering the following question:}

Do the direct foreign investments have a positive effect on decreasing poverty in the developing states? Meaning: does the increase in direct foreign cash flow result in minimizing poverty?

\section{Objectives of the Study}

The study objectives are to evaluate the effect of foreign investment on decreasing unemployment in the developing states; The host states expect from direct foreign investment to contribute in minimizing poverty in these hosting countries. Accordingly, these states attempt to create an appropriate environment to attract such investment.

\subsection{Contribution of the Study}

Experimental economic literature contains a number of studies that examined the effect of foreign investment on unemployment. In this regard, Hoa (2002) measured the effects of direct foreign investment on decreasing poverty in 61 states in Vietnam during the period 1990- 2000. The results of this study showed positive effect but not moral for foreign investment on decreasing poverty.

According to this trend, Remla (2012) conducted a study aimed at identifying the impact of foreign direct investment on poverty reduction and whether there exists a causal relationship between FDI and economic growth and poverty reduction in Ethiopia. The study was based on time series data which were collected from secondary sources and cover the period from 1970-2009. Cointegration and Vector Error Correction approaches have been applied for the 
growth model. Estimated results reveal that real per capita GDP responds negatively to FDI in the long run in Ethiopia. He pointed out that it may be a result of profit repatriation of foreign firms, crowding out of domestic investment because of FDI or low level of human capital in the country. However, in the short run, FDI was found to be insignificant in explaining real per capita GDP. When we come to Nigeria, there is a dearth of empirical literatures linking FDI to Poverty reduction. However, Adeolu (2007) conducted a study to explore empirically the relationship between FDI and GDP growth in Nigeria and also to ascertain the long-run sustainability of the FDI-induced growth process. Using the ordinary Least Square estimation technique and an augmented Solow production function, his results revealed that FDI in Nigeria induces the nation's economic growth. Although the overall effect of FDI on the whole economy may not be significant, the components of FDI positively affect economic growth and therefore FDI needs to be encouraged. Omorogbe et al. (2007) also conducted a similar study to investigate the impact of FDI on poverty reduction in Nigeria. Using per capita GDP as a proxy for poverty and an ordinary least square regression method, their findings revealed a satisfactory performance of FDI on per capita GDP in Nigeria. On the other hand, Agenor (2002) investigated the relationship between director foreign investment and poverty in 11 countries. This study showed that there is no relationship between the two variables, while Milanovic (2003) did not find any link between foreign investment and poverty, when he studied a sample that consisted of 89 countries during the period 1977-1985.

It is worth stating that the current study in consistent with Jalilian \& Weiss (2002) but what distinguishes this study from the previous ones is that it examined the effect of foreign investments on the average of income and the level of poverty for nine Asian countries. Moreover, this study shows how director foreign investments affect the average of the poor income. However, the current study is wider and extends to include 85 de:veloping countries. In addition, it is concerned with the percentage of inhabitants who are bellow poverty line. Moreover, this study differs from the previous ones (Dahan, Napal, \& Aryal, 2004) and Hadjimicheal (2001) as these two studies focused on the link between FDI and the average of economic growth, then concluding the existence or absence of the effect of foreign investments in decreasing poverty, relying on the economic development.

\subsection{Hypotheses of the Study}

Based on the above, and to achieve the objectives of this study, the following hypotheses were formulated:

The first hypothesis: there is a significant important relationship between director foreign investments and decreasing poverty.

The second hypothesis: the human capital plays a significant role in the relationship between direct foreign investments and decreasing poverty in the developing countries.

\section{Concept of Direct Foreign Investment (FDI)}

Direct foreign investment means the movement of foreign money for investment abroad in a direct way to work in industrial, financing, construction, agricultural or service units. The 
profit motive represents the main activator of such direct foreign investments (Shabanah, 1994).

Some economists define direct foreign investment as the practice of the foreign activity in another country whether in the productive or the transformative industry, as this type of investment is accompanied by the transfer of technology and the technical advantages to another country, while practicing direct supervision on the concerned project (Kenonah, 1980).

However, IMF and OECD define direct foreign investments as investment in projects inside a country, with the domination of the residents of another country (OECD, 2000). In this context, IMF clarified while defining such direct investments that the share of foreign investors should be more than $25 \%$ of the capital, or the concentration of $25 \%$ or more of the shares within the hands of one person or an organized group of investors which results in having actual domination on the policies and decisions of the project (Abdulwahhab, 1995).

According to the definition of UNCTAD, the director foreign investment is the one that results to a long- term relationship and reflects a sustainable and control by the foreign investor or establishment (the mother company) in a foreign branch that exists in a host country other than the one which they have its citizenship (Arab Est. for Investment Insurance, 1999). For the purposes of this definition, the separating line for defining direct foreign investment is the ownership of a share in the capital of a plant that belongs to the hosting country (which equals $10 \%$ of the ordinary or the power for voting). The local plant calls the investor therein as the affiliating unit or branch. With that the direct foreign investment includes a share in the capital by buying shares in the affiliated companies and re-investing the distributed profits, in addition to borrowing and securities between the mother company and the affiliated one as well as sub-contracting, management contracts and the rights for investment in license to produce commodities and services (Babaker, 2004).

From the above, it becomes clear that there is not general agreement on the provision of administrative control for the purposes of foreign investment (which is FDI); some countries and organizations consider owning 25 of a project is enough to practice administrative control, while others require owning $20 \%$ or $50 \%$ or more. However, some countries and organizations consider such figures as high on the international level, and therefore, they sought that owning $10 \%$ of the project is enough to satisfy the provision of administrative control, which was agreed by a large number of economists.

In this regard, Vaughan (1995) views direct foreign investment as taking the shape of a new productive structure (titled: Greenfield Investments). In fact, investment might take the form of re-purchasing the whole or a part of a project that really exists (called: Acquisitions and Mergers).

However, literature of direct foreign investment shows that such investments usually take the form of re-purchasing an existing project. This can be attributed to the investor's desire in such kind of investment to avoid the costs of building a new infrastructure for the project, and thus decrease the costs. It is worth stating that the motives for such kind of investments, 
which are concentrated in the slow growth of local markets of this establishment, or the need to control a market share that is larger than is products in international markets, or the desire and concern of such companies in capitalization of their immovable assets such as productive, administrative and marketing skills.

Furthermore, this kind of investment results in a larger completion between trade and investment; the director foreign investment is the most common method dlue to the economic and strategic developments, not to forget that director foreign investment enables the company to control it commercial relationships and on markets more than the benefits of exports.

Motives of director foreign investment can be uncovered through the following points (Vaughan, 1995):

1) Avoiding Trade barriers: the policies, procedures and the public programs affect the cost and competition of commodities. Therefore, direct foreign investment is the best choice to avoid high costs that are imposed by business procedures.

2) Lower production costs: the advantages of location are considered important factors for director foreign investment; the countries that cost lower wages with strategic location and a social and economic stability are deemed as an important choice for director foreign investment to minimize production costs.

3) Natural resources: the prices of imported raw materials affect the decision for director foreign investment. The director foreign investor can minimize the costs if he could obtain raw materials, commodities with lower prices in the host countries.

4) National infrastructure: costs of transport are among the important ones facing industry. To minimize such costs, there should be an appropriate infrastructure like roads, communication, ports... etc. therefore; production in the host county is the best choice in case of high transport costs.

5) International Trade Agreements: it is uncertain that the commercial policies- in specific- can be harmed upon taking investment decision. In this regard, some agreements of the free international trade allow a wider market to promote the productions of the foreign investor.

6) Environmental policy: some countries impose firm environment policies, which force companies to pay large amounts for having a friend environment. Accordingly, it is expected that the softer environmental countries will be an important choice for director foreign investment to minimize such costs.

7) Intellectual capital: local and international policies play an important role in creating intellectual capital and the protection of royalty as well as RD activities. Such policies provide a wide based for the intellectual capital under laws for the protection of royalty in the host country, which is considered important factors in attracting direct foreign investment. 
8) Tax laws and population growth in the hosting country: high taxes on some goods especially the commodities/ luxurious affect consumption. In return, the growth of population means a larger market for the products, not to forget that the purchase power of the citizens of the host country plays an important role in attracting direct foreign investment.

\section{The Direct Effects of Direct Foreign Investments on Manpower and Decreasing Poverty}

During the seventies, many of the governments of the developing countries did not use to welcome direct foreign investment due to the intention to achieve revenue profits (by the multinational companies) without care to improve the economies of these countries. However, during the eighties, this perspective has differed and viewed as having the ability not only to affect production, but also on the average of the growth of such production (1), in addition to helping in the development and training of human resources (Hassan, 2004).

As a matter of fact, direct foreign investments can affect decreasing poverty through its influence in manpower; the increase of direct foreign investments results in increasing job opportunities from one perspective and contributes in the training of the local manpower that have job opportunities in the branches of foreign companies while gaining technical modern skills using the latest modern work methods and training, from the other (Hoa, 2002) (1). Accordingly, the increase of direct foreign investments will result in a direct increase of manpower, which cause decreasing the current unemployment, therefore, minimize the number of poor who live under poverty line.

The effect of direct foreign investments on manpower can be explained through various indicators, including:

1) The direct foreign investments affect the size of manpower through the jobs available in the foreign companies for the citizens of the host country.

2) The direct foreign investments affect in the quality of manpower, where foreign companies pay higher wages to employees in order to raise their production.

3) The direct foreign investments affect the location of manpower through the provision of new jobs in regions that have high levels of unemployment.

Various studies confirmed the existence of a positive effect for direct foreign investments in decreasing poverty (Saravanamuttoo, 1999). The positive effect of direct foreign investments on manpower does not only indicate to the manpower that can be created inside the foreign companies (direct manpower), but also to the manpower that is created in the affiliated companies whether in horizontal or vertical way (the indirect manpower). A study by Aaron (2005) indicated that the effect of direct foreign investments on manpower in the developing countries amounted to 26 million job opportunities in 1997 . The same study indicated that the indirect effect on manpower in such countries was estimated for 1.6 job opportunities per on job opportunity.

On the other side, some economists believe that FDI does not play an important role in the field of providing the national manpower with the modern technology skills due to lack of job 
opportunities produced by such investments as they use highly costing technology methods. Moreover, the effect of FDI on work is minor and mainly relies on the movement of labors among industries, not to forget that such manpower usually practices secondary tasks. This was confirmed by some studies which concluded that FDI prefers using skills labors and is not fair in recruiting local manpower. In addition, they prefer using unskilled labors in locations where such labor is a rare source (Gatson \& Nelson, 2001), and perhaps this motivated the researcher to study the effect of FDI on decreasing poverty in the developing countries.

\section{Effect of DFI on Decreasing Poverty in the Developing Countries (A Measurable Study)}

From a theoretical perspective, the effect of DFI has become clear on decreasing poverty. Accordingly, to study this effect in practice can enrich this study, as the main purpose is to show the effect of such investment on decreasing poverty during the period (1980-2012) through defining the quantitative effect left by the DFI on poverty.

\section{The Measurable Analysis Models}

Literature of poverty studies assume that it be shown through the flows of DFI as well as other features such as human capital, the degree of commercial openness, the average of inflation, variation in income distribution, democracy etc. (Sylwester, 2005). Accordingly, the researcher believes that the practical analysis for the effect of DFI cash flow on decreasing poverty requires a series of features relevant to the developing countries, as follows:

1) Net cash flow of DFI: DFI directly results in decreasing poverty through its influence on manpower; the increase of DFI results in an increase of job opportunities, from one perspective, and contributes in training the local manpower which have job opportunities in various branches of the foreign companies to gain modern technical skills and using the latest work methods and training from the other (Hoa, 2002). Therefore, the increase of DFI will result in increasing manpower in a direct way, and in return, results in decreasing the current unemployment, which will minimize the number of poor who live under poverty line.

2) The individual's share of GDP: the economic theory indicates that an increase in one's share of income will improve the living standards of the poor (Dollar \& Kraay, 2001).

3) Human capital: an approximation is usually used for this indicator, namely the percentage of those who enrolled in secondary education. This approximation is the most comprehensive compared with other measures (Polani \& Bakhash, 2001).

4) First of all, it is necessary to measure the minimum limit of human capital to make the best use of the cash flow of foreign investments to the poor countries. However, foreign investment expects a minimum limit of technical skills, education and knowledge by the employees and citizens of the host county, not only to manage the cash flows, but also to make use of the DFI in motivating the economic growth. However, in case there is not minimum limit of skills, investment cash flows will increase the level of foreign manpower as will limiting the abilities of organizations in the host countries from putting policies and 
programs that motivate the poor and include them in the foreign companies. In general, the human capital (in theory) contributes in decreasing poverty, and therefore, the expected sign of the coefficient of this variable is negative; meaning, the increase in human capital, the more it is linked with lower levels of poverty.

5) Population growth: it is well-known that the average of population growth in the developing countries surpasses the growth of the economic resources which are necessary to enhance the production of goods and services. Consequently, this causes an exaggeration in using the available resources, and leads to increasing poverty.

6) Corruption: some economists believe that public corruption is a strong indicator to believe about the failure of distributing the items of the budget in a way that enhances recruitment, medical and educational services as well as other variables that limit poverty (Chetwynds \& Specter, 2003). Therefore, foreign investors may hesitate in the countries that suffer of high levels of corruption in the public structure, which also may affect the commercial operation. Accordingly, the coefficient of public corruption might have a positive relationship with the percentage of poverty.

7) Democracy: there are clear evidences indicating that the highly democratic countries will attract foreign investments, which might be motivating for growth.

8) Degree of economic openness: the foreign trade theory states that minimizing commercial obstacles will speed growth, which in turn will minimize poverty. Adding that foreign companies consider commercial barriers as of the most criteria that control guiding their investments.

9) Inflation level: some economists believe that high inflation levels result in hindering economic development and increase poverty in the developing countries, considering that wages are not in harmony with inflation which may expose real wages to decrease. Adding that the poor are the most harmed from inflation as their savings are kept on the form of cash liquidity (Easterl \& Fischer, 2003).

10) Variation in income distribution: used to express the variation in income distribution among the citizens. GINI will be used to express this variation, whose value is limited between zero and one. This distribution takes its worst states when the value of GINI equals one. The smaller value of this coefficient the better justice in income distribution.

11) In order to know the effect of director foreign investments on decreasing poverty in the developing countries, the researcher with use an amended form of the standard model used in various applied economic studies relevant with measuring this effect as follows (Jalinlian \& Weiss, 2002):

$$
P_{i t}=\lambda+\alpha \sum_{i=1}^{i} X_{i t}+\varepsilon_{i t}
$$

\subsection{Where}

Pit: the relative change in poverty measure through Headcount index. It shows the number of 
poor as a percentage of the total population in the community. The Headcount ration will be used for those who live on less than $\$ 1,25$ per day (as a measure for poverty) (Ravallion, 2001; Iradian, 2007).

Xit: Vector explained the change in the net of internal cash flows of the FI as a percentage of the GDP. And the change in the percentage of total individuals enrolled in secondary education, as an approximation for the human capital, and the change in the individual's share of the GDP, and the other influencing factors such as the change in the growth of population, corruption, democracy and commercial openness.

The researcher believes that using changes in the variables instead of using the levels are the most appropriate to obtain consistent results for the coefficients in this study due to the following reasons:

1) From a measurable perspective, using the first difference or the relative change will limit the problem of instability of the time frames, in addition, using natural logarithm in some variables will also limit the problem of non- stability which still existing. The main purpose of using natural logarithm is decreasing the effect of rapid growth of some variable (exponentially growing variables).

2) There is a need to consider the inconsistency between the countries in defining poverty as well the data and methodology used in defining it. For example, some countries define poverty as the percentage of population living on less than one $\$$ dollar per day, while other countries define it as the percentage of population who live on less than $\$ 2$ per day. On the same time, some countries rely on the data of consumption flow that are available in the country about poverty. Other countries depend on income data and consider the least fifth (in terms of income) as a measure for poverty (Jallilian \& Weiss, 2002). This created inconsistency in the relevant data.

Accordingly, preserving one pattern of data for each country using the changes, will make it easy to avoid such variations between the countries of the developing world.

In most cases, poverty has historical and civilized roots, which cannot be changed on the short run or even the medium run. Consequently, the use of changes in the levels of poverty might be logical, since the relationship between poverty and the independent variables will depend on the effect of the changes of the independent ones on the change in poverty, but not merely a reflection of the current level of the variable at a specific time point. Meaning that level analysis of the relationship between poverty and FI will allow limiting the current relationship between investment and poverty as well as not allowing knowing the potential change in the levels of poverty that result from the changes in the levels of foreign investments.

3) Finally, it is worth stating that the economic theory believes that increasing the individual's share of income will improve the income level of the poor. Therefore, the question that arises: is: is there any effect for DFI on the level of poverty upon separating the effect of growth? 
Consequently, the study will use the model twice: first: estimating the coefficient of DFI without the average of income growth. In case there is a significant statistical effect, it will be difficult to judge whether this effect is attributed to the DFI in separation of the effect of growth. Therefore, the second estimation of investment coefficient on poverty will be with the existent of growth average; in case no effect for DFI on poverty, then foreign investment coefficient should equal (Zero). Accordingly, growth coefficient will play a significant role in defining the effect of DFI.

In return, in case the coefficient of investments was of a statistical significance, this shows that foreign investments cause some effect on poverty in separation of the effect of growth. However, in case of negative coefficient of foreign investments, then it results to the alternative hypotheses, that foreign investments affect on decreasing poverty.

\subsection{Sources of Data Used in the Model}

The study includes 85 developing countries (Appendix A), which represent the various developing countries in the world.

1) Source of poverty percentage data: it is the data base of World Bank. The Headcount index was used as a measurement for poverty, while using Headcount ration for the families living on less than $\$ 1.25$ depending on the data of consumption distribution in the countries under study. Despite the continuous amendments of the World Bank on this indicator, the Bank is still providing a wide data base for poverty about most of the developing countries (website: www.worldbank.org/povcalNet)

2) Net cash flows of DFI were obtained from WDI (Worldwide Development Indicators). In addition, they could be obtained from (IFS) "International Finance Statistics).

3) To show corruption data, the study relies on the data base issued by PRS Group and Maryland University. It is available on the website: www.prsgroub.com. This measure is limited between ( 0 : the more corrupt) and ( +10 the least corrupt).

4) Source of Gross Fixed Capital Formation; Trade openness, Human Capital, Infrastructure, and Unemployment were obtained from (website: www.worldbank.org/povcalNet)

\subsection{Results of the Measurable Estimation of the Model}

To measure the effect of FDI on decreasing poverty, equitation (1) was used according to OLS on three stages, the first: estimating the model without the growth and GINI variables, the second stage: adding the two above said variables, the third: the researcher will insert the interaction limit between FDI and the human capital.

\section{Estimating the Effect of FDI on Decreasing Poverty without the Growth and GINI Variables}

To measure the effect of FDI on decreasing poverty, the model of the study was estimated using the minor small quarters and by using unbalanced panel data for the period 1980- 2012 . This resulted in the following conclusions (shown in tables 1-4) after making sure that we can 
not reject the zero hypotheses with the absence of self link (grade 1).

Poverty $=\mathrm{f}(\mathrm{OPEN}$, GFCF, GOVSIZE , INFR, INFL,UNEMP, HUMCAP, FDI)

The econometric form of the model can be expressed as:

Povt $=\beta 0+\beta 1$ OPENt $+\beta 2$ GFCFt $+\beta 3$ GOVSIZEt $+\beta 4$ INFRt $+\beta 5$ FDIt $+\beta 6$ UNEMPt $+\beta 7$ INFLt $+\beta 8$ HUMCAPt $+\mu$

\subsection{Where}

Where: Pov = Poverty; GFC $=$ Gross Fixed Capital Formation; GOVSIZE = Government Size; OPEN=Trade openness; HUMCAP= Human Capital; INFR =Infrastructure; INFL $=$ Inflation; UNEMP $=$ Unemployment; FDI $=$ Foreign Direct Investment; and $\mu=$ the stochastic error term.

Table 1. Augmented Dickey-Fuller (ADF) unit root test

\begin{tabular}{|l|l|l|l|l|l|}
\hline VARIABLES & \multicolumn{2}{|l|}{ LEVEL } & \multicolumn{2}{l|}{$\mathbf{1}^{\text {st }}$ DIFFERENCE } & I(d) \\
\hline & $\begin{array}{l}\text { Critical } \\
\text { values }\end{array}$ & $\begin{array}{l}\text { ADF-Test } \\
\text { Statistics }\end{array}$ & Critical values & $\begin{array}{l}\text { ADF-Test } \\
\text { Statistics }\end{array}$ & $\begin{array}{l}\text { Order of } \\
\text { Integration }\end{array}$ \\
\hline Pov & -0.525990 & -2.885451 & -2.983548 & -2.944972 & $\mathrm{I}(1)$ \\
\hline FDI & -0.236917 & -2.857150 & -6.437548 & -2.964416 & $\mathrm{I}(1)$ \\
\hline OPEN & 0.394544 & -2.860511 & -6.907584 & -2.940414 & $\mathrm{I}(1)$ \\
\hline HUMCAP & -0.025218 & -2.857150 & -4.728605 & -2.940412 & $\mathrm{I}(1)$ \\
\hline INFR & 0.688233 & -2.863952 & -6.309503 & -2.964971 & $\mathrm{I}(1)$ \\
\hline INFL & -2.20612 & -2.857115 & -3.331076 & -2.964411 & $\mathrm{I}(1)$ \\
\hline GOVSIZE & 0.254506 & -2.857115 & -5.499478 & -2.940414 & $\mathrm{I}(1)$ \\
\hline UNEM & 0.355274 & -2.857110 & -4.3552812 & -2.940414 & $\mathrm{I}(1)$ \\
\hline GFCF & 1.65811 & -2.81888 & -3.865172 & -2.948068 & $\mathrm{I}(1)$ \\
\hline
\end{tabular}

From the results shown in table (1), the following is noted: all the variables are not stationary at the level but they all became stationary after taken their first difference.

The stationarity test results presented previously indicate that all the variables are not level stationary. This suggests that regression based on the level variables may produce an unreliable outcome. However, the Granger representation theorem states that it is possible for non-stationary variables to produce a stationary relationship if they are co integrated. This would imply that there is a meaningful long run relationship among the variables. 


\section{Macrothink}

Table 2. Summary of estimated long run model; dependent variable: Pov

\begin{tabular}{|l|l|l|l|l|}
\hline Variable & Coefficient & Std. Error & t-Statistic & Prob. \\
\hline C & 29.71939 & 18.29267 & 1.624661 & 0.1173 \\
\hline FDI & 0.000301 & 0.000336 & 0.893490 & 0.3805 \\
\hline GFCF & 0.061836 & 0.097558 & 0.633839 & 0.5322 \\
\hline GOVSIZE & -0.157415 & 0.054116 & -2.908899 & 0.0068 \\
\hline INFL & -0.128709 & 0.131276 & -0.980449 & 0.3366 \\
\hline INFR & 0.022989 & 0.005202 & 4.419433 & 0.0002 \\
\hline OPEN & $8.63 \mathrm{E}-05$ & $3.09 \mathrm{E}-05$ & 2.793310 & 0.0101 \\
\hline HUMCAP & -0.616284 & 3.768193 & -0.163549 & 0.8715 \\
\hline UNEM & -1.055944 & 1.248889 & -0.845507 & 0.4062 \\
\hline R-squared & & $\mathbf{0 . 9 6 7}$ & F-statistic & $\mathbf{8 9 . 1 0}$ \\
\hline Adjusted R-squared & $\mathbf{0 . 9 5 7}$ & Prob(F-statistic ) & $\mathbf{0 . 0 0 0}$ \\
\hline
\end{tabular}

The above result shows that the long run impact of FDI on poverty is found positive but not significant. This implies that it has little impact on poverty in the long run. Accordingly, the previous results confirm that DFI has no effect in decreasing poverty in the developing countries.

\section{Estimating the Short Run Relationships of DFI on poverty:}

In order to measure the short run effect of DFI on poverty, the model of the study was estimated. Table 4 shows the results of the DP equation in the error-correction model, from which the short-run impact of FDI, openness, infrastructure, human capital, inflation, unemployment, gross fixed capital formation and government size on real per capita GDP can be analyzed.

$$
\begin{gathered}
\mathrm{DPOVt}=\beta 0+\beta 1 \mathrm{DOPENt}+\beta 2 \mathrm{DGFCFt}+\beta 3 \text { DGOVSIZEt }+\beta 4 \text { DINFRt }+\beta 5 \text { DFDIt }+\beta 6 \\
\text { DUNEMPt }+\beta 7 \text { DINFLt }+\beta 8 \text { DHUMCAPt }+\mu
\end{gathered}
$$

\subsection{Where}

Where: Pov $=$ Poverty; GFC $=$ Gross Fixed Capital Formation; GOVSIZE $=$ Government Size; OPEN=Trade openness; HUMCAP= Human Capital; INFR =Infrastructure; INFL $=$ Inflation; UNEMP $=$ Unemployment; FDI $=$ Foreign Direct Investment; and $\mu=$ the stochastic error term. 


\section{Macrothink}

Table 3. Estimation of the short run effect of direct foreign investment on poverty

\begin{tabular}{|l|l|l|l|l|}
\hline Variable & Coefficient & Std. Error & t-Statistic & Prob. \\
\hline ECM(-1) & -0.33189 & 0.13279 & -2.81043 & 0.0108 \\
\hline $\mathrm{C}$ & 2.24514 & 2.33244 & 1.11245 & 0.3121 \\
\hline $\mathrm{dFDI}$ & 0.00024 & 0.00011 & 1.53614 & 0.1254 \\
\hline $\mathrm{dGFCF}$ & 0.08745 & 0.04584 & 1.59541 & 0.2101 \\
\hline dGOVSIZE & -0.09954 & 0.05486 & -1.88214 & 0.0814 \\
\hline dINFL & 0.01245 & 0.00325 & 3.25614 & 0.0022 \\
\hline dINFR & -0.28746 & 0.06545 & -5.54621 & 0.0004 \\
\hline dOPEN & $4.22 \mathrm{E}-03$ & $1.40 \mathrm{E}-03$ & 2.98451 & 0.0094 \\
\hline dHUMCAP & 0.33255 & 2.85542 & 0.13541 & 0.7584 \\
\hline dUNEM & -0.20545 & 0.95421 & -0.15465 & 0.8957 \\
\hline R-squared & & $\mathbf{0 . 7 4 2 5 4}$ & F-statistic & $\mathbf{6 . 2 4 5 1}$ \\
\hline Adjusted R-squared & $\mathbf{0 . 6 3 2 5 5}$ & Prob(F-statistic ) & $\mathbf{0 . 0 0 1}$ \\
\hline Durbin-Watson stat & $\mathbf{1 . 9 1 2 4}$ & & \\
\hline
\end{tabular}

From the results shown in table (3), the following is noted:

1) The coefficient of the error correction term for the equation is negative and significant as expected. The error correction term of -0.33 shows that about 33 percent of the deviation of poverty from its equilibrium value is eliminated every year

2) FDI is insignificant in the short run model indicating that it does not have a major impact on poverty in the short run, just like in the long run.

Accordingly, the previous results confirm that FDI has no direct relationship in decreasing poverty in all cases- whether by inserting development or not- as FDI has no direct effect on the level of poverty. In addition, the results showed that development is the only variable in decreasing poverty. This role is confirmed by the high level of corrected definition of the model after inserting growth.

\section{Estimating the Effect of Interaction between FDI and the Human Capital on Decreasing Poverty}

In order to investigate the mixed reaction as to whether FDI influences poverty reduction or the allegation that multinationals situate their investment in a country where there is high level of poverty with the intention to exploit the people further; the granger causality test is conducted to investigate.

\subsection{Where}

Using the FDI and Poverty panel data for the period 1980- 2012, the results shown in table (3) were reached. 
Table 4. The results of estimating the effect of director foreign investment on poverty

\begin{tabular}{|l|l|l|}
\hline Null Hypothesis & F-Statistic & Prob. \\
\hline FDI does not Granger Cause poverty reduction & 1.21454 & 0.2145 \\
\hline Poverty reduction does not Granger Cause FDI & 1.32145 & 0.3215 \\
\hline
\end{tabular}

Among the results shown in table (4), there is no causal relationship between FDI and poverty in developing countries. This means that the level of poverty does not have any influence on foreign capital flow, in form of FDI, into the country as claimed by the antagonist of foreign direct investment.

\section{Results and Recommendations}

\subsection{First: the Study Concluded with A Set of Results, Mainly}

1) There is a weak immoral effect for direct foreign investments on poverty in the developing countries regardless of the existence or absence of development.

2) There is a no effect for GDP on poverty; the increase in the average income of an individual may decrease poverty. The size of decrease depends on variation (inequality) on the long range.

3) We concluded that this may be a result of profit repatriation of foreign firms, crowding out of domestic investment because of FDI or low level of human capital in the country.

10.2 Second: In Order to Minimize the Number of Poor as a Percentage of the Total Population in the Developing Countries through Director Foreign Investments, Policy Makers in these Countries should Attempt to Achieve the Following:

1) Despite how desirable the inflow of FDI is to developing countries, care should be taken when attracting foreign investments and they should be directed to the productive sectors of the economy.

2) Also government should create a competitive environment so as to maximize the benefits of FDI because by exposing foreign investors to an even playing field with indigenous investors.

3) Continue in applying the open-door policy and increasing the degree of economic openness.

\section{References}

Aaron, C. (2005). The Contribution of FDI to Poverty Alleviation. [Online] Available: www.fias.ner/../\&FILE/Contribution+of+FDI+to+Poverty+Allocation+-+Carl+Aaron.pdf- 
Abu Qahaf, A. (1989). Theories of internalization and the feasibility of foreign investments. Shabab Al-Jame’a Est. (pp. 174-176).

Agenor, P. (2002). Does Globalization Hurt the Poor? World Bank Policy Research Working Paper No. 20433, pp. 1-32.

Arab Est for Investment Insurance. (1999). Direct foreign investment and effect on development, a series of focused conclusions. Kuwait, p. 2.

Babaker, M. (2004). Development of director foreign investment. A program prepared by the Arab Institute for Planning in Kuwait, in cooperation with information center and was supported by a ministerial resolution in Egypt, pp. 2-3.

Calvo, C., \& Hernandez, M. A. (2006). Foreign Direct investment and Poverty in Latin America. [Online] Available:

Nottingham.ac.uk/economics/leverhulme/.../MarcoHernandez.pdf

Chetwynd, F., Chetwynd, E., \& Spector, B. (2003). Corruption and Poverty: A Review of Recent Literature. Management Systems International (pp. 4-20). [Online] Available: http://www.u4.no/document/literature/corruption-and-poverty.pdf

Dahan, K., Nepal, G., \& Aryal, S. (2004). A study of Impact of Foreign Direct Investment policy of Rich Countries on Poverty Reduction of Developing Countries: A case Study of Manufacturing Sector in Nepal. IDDS, pp. 1-11, 49.

Dawood, H. (2010). The effects of foreign investment in the transformational industrial sector in Jordan during the period 1995- 2006. A PhD under the supervision of Dr. Taleb Awadh and Prof. Dr. Ahmed Oran, presented to the Faculty of Business, UJ, Jordan.

Dollar, D., \& Kraay, A. (2005). Growth is Good for the poor. Policy Research Working Paper $\begin{array}{lllll}\text { No.2587, } & \text { 1-35. } & \text { [Online }] & \text { Available: }\end{array}$ http://www.springerlink.com.proxy.lib.siu.edu/content/102931/

Easterl, W., \& Fischer, S. (2001). Inflation and the poor. Journal of Money, Credit and Banking, 33(2), 1-32. https://doi.org/10.2307/2673879 
Iradian, G. (2005). Inequality, Poverty and Growth: Cross Country Evidence. IMF Working Paper, pp. 1-15. https://doi.org/10.5089/9781451860474.001

Gaston, N., \& Nelson, D. (2001). Integration, FDI and Labour Markets: Microeconomic Perspectives.

Hassan, M. (2003). FDI, Information Technology and Economic Growth in Mena Region. [Online] Available: www.erf.org.eg/eenthconf/trade-presenetd/kabair_hassan.pdf

Hoa, N. T. P. (2002). Contribution of Foreign Direct Investment to poverty Reduction: The Case of Vietnam in the 1990s. [Online] Available: zef.de/module/.../media/e086_FDI

Hung, T. T. (2005). Impacts of Foreign Direct Investment on Poverty Reduction in Vietnam. [Online] Available: www.grips.as.jp/vietnam/VDFTokyo/Doc/18TTHungPaper.pdf

Ibrahim, A. (1995). Direct foreign investment and effect on economic development in Egypt during the period 1974-1990. (MA thesis) Alexanderia, pp. 12-13.

Iradian, G. (2007). Repaid Growth in the CIS: Panel Regression Approach. IMF Working Paper, $\quad$ pp. $1-15$ [Online] Available: http://www.imf.org/external/pubs/ft/wp/2007/wp07170.pdf

Jalilian, H., \& Weiss, J. (2002). Foreign Direct Investment and Poverty in the ASEAN Region. Asian Economics Bulletin, 19, 231-253. https://doi.org/10.1355/AE19-3A

Kenona, A. (1980). International economy, Mustansiria University, Baghdad.

Klein, M., Aaron, C., \& Hadjimicheal, B. (2001). Foreign Direct Investment and poverty reduction. Policy Research Paper, 2613, 1-25. https://doi.org/10.1596/1813-9450-2613

MIlanovic, B. (2003). Can we Discern the Effect of Globalization on Income Distribution? World Bank Development Research Group (pp. 4-28). [Online] Available: http://129.3.20.41/eps/hew/papers/0310/0310002.pdf

Mold, A. (2004). FDI and Poverty Reduction: A Critical Re-appraisal of the Arguments. [Online] Available: www.regionetdeveloppement.u-3mrs.fr/pdf/R20_mold.pdf 
Noor Baksh, F., Paloni, A., \& Youssef, A. (2001). Human Capital and FDI Inflows to

Developing Countries: New Empirical Evidence. World Development, 29, 1593-1610. https://doi.org/10.1016/S0305-750X(01)00054-7

PRS group and University of Maryland. (2010). International Country Risk Guide [Corruption]. [Online] Available: http://www.prsgroup.com

Ravallion, M. (2001). Growth, Inequality and Poverty: Looking Beyond Averages. World Development, 29, 1803-1815. https://doi.org/10.1016/S0305-750X(01)00072-9

Saravanamutoo, N. (1999). Foreign Direct Investment and Poverty Reduction in Developing Countries. [Online] Available: acdicida.go.ca/INET/IMAGES/LUImages/PovertyReduction/Fdi.pdf

Shabana, A. (1994). The role of director foreign investment in financing the economic development in Egypt in light of the market mechanisms, the 8th scientific conference for Egyptian Economists: financing the development in light of market economies. Cairo, p. 2.

Soto, M. (2000). Capital Flows and Growth in Developing Countries: Recent Empirical Evidence. OECD Development Centre Technical Paper No. 160, Paris: OECD. https://doi.org/10.1787/633871307443

Sylwester, K. (2005). Foreign Direct Investment, Growth and Income Inequality in less Developed countries. International Review of Applied Economics, 19, 289-300. https://doi.org/10.1080/02692170500119748

UNCTAD. World Investment Repot. [Online] Available: http://www.unctad.org/en/docs/wir_en.pdf

UNISCO Institute for Statistics. Gross Secondary Enrollment Ratio [Education]. [Online] Available: http://stats.uis.unesco.org/unesco/ReportFolders/ReportFolders.aspx?

Vaughan, S. (1995). Implications of Foreign Direct Investment for the Canadian Food and Beverage Manufacturing Industry. Industry Competitiveness Group, Ottawa, Ontario, K1A 0C5, (613), 995-5880. 
World Bank. (2010). Povcalnet online poverty analysis tool. [Online] Available: http://iresearch.worldbank.org/PovcalNet/povcalNet.html

World Bank. World Development Indicators. Available on CD-rom.

World Bank. World Development Report. [Online] Available: http://siteresources.worldbank.org//Resources/complete_report.pdf 


\section{Appendix A.}

Sample of the 85 Countries include in the Study

\begin{tabular}{|c|c|c|c|c|c|}
\hline 1 & Argentina & 30 & Indonesia & 59 & Philippines \\
\hline 2 & Albania & 31 & Islamic Republic of Iran & 60 & Poland \\
\hline 3 & Algeria & 32 & Jordan & 61 & Porkina Faso \\
\hline 4 & Azerbaijan & 33 & Kazakhstan & 62 & Postuana \\
\hline 5 & Bangladesh & 34 & Kenya & 63 & Republic of Egypt \\
\hline 6 & Benin & 35 & Kyrgyzstan & 64 & Romania \\
\hline 7 & Bolivia & 36 & Latvia & 65 & Russia \\
\hline 8 & Brazil & 37 & Lau Democratic Republic & 66 & Rwanda \\
\hline 9 & Bulgaria & 38 & Lesotho & 67 & South Africa \\
\hline 10 & Burundi & 39 & Lithuania & 68 & Sri Lanka \\
\hline 11 & Cameron & 40 & Madaghashqar & 69 & Tajikistan \\
\hline 12 & Chilly & 41 & Magharabi & 70 & Thailand \\
\hline 13 & China & 42 & Magnolia & 71 & Trinidad and Tobago \\
\hline 14 & Colombia & 43 & Malaysia & 72 & Tunisia \\
\hline 15 & Cost de Ivory & 44 & Maqadonia & 73 & Turkey \\
\hline 16 & Costa Rica & 45 & Mauritania & 74 & Uganda \\
\hline 17 & Dominican Republic & 46 & Mexico & 75 & Ukraine \\
\hline 18 & Ecuador & 47 & Mexico & 76 & Uruguay \\
\hline 19 & El Salvador & 48 & Middle Africa & 77 & Uzpakistan \\
\hline 20 & Estonia & 49 & Moldavia & 78 & Venezuela \\
\hline 21 & Ethiopia & 50 & Nepal & 79 & Vietnam \\
\hline 22 & Georgia & 51 & New Babul Ginia & 80 & White Russia \\
\hline 23 & Ghana & 52 & Nicaragua & 81 & Yemen \\
\hline 24 & Ghinia Pisau & 53 & Niger & 82 & Zambia \\
\hline 25 & Guatemala & 54 & Nigeria & 83 & Uzpakistan \\
\hline 26 & Guinea & 55 & Pakistan & 84 & Vietnam \\
\hline 27 & Honduras & 56 & Panama & 85 & Yemen \\
\hline 28 & Hungaria & 57 & Paraguay & & \\
\hline 29 & India & 58 & Peru & & \\
\hline
\end{tabular}




\section{Copyright Disclaimer}

Copyright for this article is retained by the author(s), with first publication rights granted to the journal.

This is an open-access article distributed under the terms and conditions of the Creative Commons Attribution license (http://creativecommons.org/licenses/by/3.0/). 